STATE OF ILLINOIS

DWIGHT H. GREEN, Governor

DEPARTMENT OF REGISTRATION AND EDUCATION

FRANK G. THOMPSON, Director

DIVISION OF THE

STATE GEOLOGICAL SURVEY

M. M. LEIGHTON, Chief

URBANA

REPORT OF INVESTIGATIONS-No. 113

\title{
KINKAID CORALS FROM ILLINOIS \\ ANI) \\ AMPLEXOID CORALS FROM THE CHESTER OF ILLINOIS \\ AND ARKANSAS
}

BY

WM. H. EASTON

Reprinted from Journal of Paleontology, Vol. 19, Nos. 4 and 6, 1945

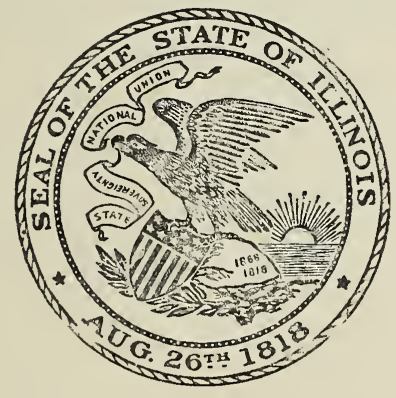

PRINTED BY AUTHORITY OF THE STATE OF ILLINOIS

URBANA, ILLINOIS 


\section{ORGANIZATION}

STATE OF ILLINOIS

HON. DWIGHT H. GREEN, Governor

DEPARTMENT OF REGISTRATION AND EDUCATION

HON. FRANK G. THOMPSON, Director

\section{BOARD OF NATURAL RESOURCES AND CONSERVATION \\ HON. FRANK G. THOMPSON, Chairman \\ NORMAN L. BOWEN, Pн.D., D.Sc., LL.D., Geology \\ ROGER ADAMS, Рн.D., D.Sc., Chemistry \\ LOUIS R. HOWSON, C.E., Engineering \\ CARL G. HARTMAN, Рн.D., Biology \\ EZRA JACOB KRAUS, PH.D., D.Sc., Forestry \\ ARTHUR CUTTS WILLARD, D.ENGR., LL.D. \\ President of the University of Illinois}

\section{GEOLOGICAL SURVEY DIVISION}

M. M. LEIGHTON, Ohief 


\section{SCIENTIFIC AND TECHNICAL STAFF OF THE \\ STATE GEOLOGICAL SURVEY DIVISION}

100 Natural Resources Building, Urbana

M. M. Leighton, Pr.D., Chief

ENID TownLEY, M.S., Assistant to the Chief

Velda A. Millard, Junior Asst, to the Chief

Helen E. MCMorris, Secretary to the Chief

EFfie Hetishee, B.S., Geological Assistant

\section{GEOLOGICAL RESOURCES}

Ralph E. Grim, Ph.D., Petrographer and Principal Geologist in Charge

Coal

G. H. CADy, Pr.D., Senior Geologist and Head

L. C. MCCABE, PH.D., Geologist (on leave)

R. J. Helfinstine, M.S., Mech. Engineer

Charles C. Boley, M.S., Assoc. Mining Eng.

BRYAN ParKs, M.S., Asst. Geologist

Earle F. TAylor, M.S., Asst. Geologist (on leave)

RalPh F. Strete, A.M., Asst. Geologist

Robert M. Kosanke, M.A., Asst. Geologist

ROBERT W. EllingwOOd, B.S., Asst. Geologist

GeORge M. Wilson, M.S., Asst. Geologist

AR Nold Eddings, B.A., Research Assistant (on leave)

Raymond Siever, B.S., Research Assistant (on leave)

Toh N A. Harrison, B.S., Research Assistant (on leave)

Mary E. Barnes, B.S., Research Assistant

Margaret Parker, B.S., Research Assistant

Elizabetir Lohmann, B.F.A., Technical Assistant

\section{Oil and Gas}

A. H. Bell, Pri.D., Geologist and Head

Frederick SQuires, B.S., Petroleum Engineer

Stewart Folk, M.S., Assoc. Geologist (on leave)

ERnest P. DuBois, Ph.D., Assoc. Geologist

David H. Swann, Ph.D., Assoc. Geologist

Virginia Kline, Ph.D., Assoc. Geologist

PaUl G. LuCKhard, M.S., Asst. Geologist

(on leave)

Wayne F. Meents, Asst. Geologist

JAMES S. Yolton, Asst. Geologist

Margaret Sands, B.S., Research Assistant

\section{Industrial Minerals}

J. E. Lamar, B.S., Geologist and Head

H. B. Willman, Ph.D. Geologist

Robert M. Grogan, Ph.D., Assoc. Geologist

ROBERT T. ANDERSON, M.A., Asst. Physicist

ROBERT R. REYNOLDS, M.S., Asst. Geologist

MaRgaret C. Godwin, A.B., Asst. Geologist

\section{Clay Resources and Clay Mineral Technology}

Ralph E. Grim, Ph.D., Petrographer and Head Richards A. Rowland, Ph.D., Asst. Petrographer (on leave)

William A. White, B.S., Research Assistant

\section{Groundwater Geology and Geophysical Exploration}

CARL A. Bays, Pr.D., Geologist and Engineer, and Head

Robert R. Storm, A.B., Assoc. Geologist

Arnold C. Mason, B.S., Assoc. Geologist (on leave)

MerLy N B. Buhle, M.S., Asst. Geologist

M. W. Pullen, Jr., M.S., Asst. Geologist

Charles G. Johnson, A.B., Asst. Geologist (on leave)

Margaret J. Castle, Asst. Geologic Draftsman

Robert N. M. Urash, B.S., Research Assistant

\section{Areal and Engineering Geology}

George. E. Ekblaw, Ph.D., Geologist and Head

Richard F. Fisher, M.S., Asst. Geologist

\section{Stratigraphy and Paleontology}

J. Marvin Weller, Ph.D., Geologist and Head Chalmer L. CoOper, Ph.D., Geologist

Heinz A. Lowenstam, Ph.D., Assoc. Geologist

\section{Subsurface Geology}

L. E. Workman, M.S., Geologist and Head. C. Leland Horberg, P̈h.D., Assoc. Geologist Fran K E. Tippie, B.S., Asst. Geologist

Paul Herbert, Jr., B.S., Asst. Geologist

Marvin P. Meyer, B.S., Asst. Geologist

Elizabeth Pretzer. A.B., Research Assistant

Rutir E. Roth, B.S., Research Assistant

Physics

R. J. Piersol, Ph.D., Physicist

B. J. GreEN wood, B.S., Mech. Engineer

\section{GEOCHEMISTRY}

Frank H. Reed, Ph.D., Chief Chemist (on leave)

Carol J. Adams, B.S., Research Assistant

Coal

G. R. Yоне, Рн.D., Chemist and Head*

Herman S. Levine, B.S., Research Assistant

\section{Industrial Minerals}

J. S. Machin, Pri.D., Chemist and Head

Delbert L. Hanna, A.M., Asst. Chemist

\section{Fluorspar}

G. C. Finger, Ph.D., Chemist and Head

Oren F. Williams, B.Engr., Asst. Chemist

\section{Chemical Engineering}

H. W. JACKMAN, M.S.E., Chemical Engineer and Head P. W. Henline, M.S., Assoc. Chemical Engineer

James C. McCullough, Research Associate

Donald M. Fort, M.S., Asst. Chemist

JAMES H. HanEs, B.S., Research Assistant (on leave)

Leroy S. Miller, B.S., Research Assistant (on leave)

\section{$X$-ray and Spectrography}

IV. F. Bradley, Ph.D., Chemist and Head

\section{Analvtical}

O. IV. Rees, Pr.D., Chemist and Head*

L. D. MCVICKER, B.S., Chemist

Howard S. Clark, A.B., Assoc. Chemist

William F. Wagner, M.S., Asst. Chemist

Cameron D. Lewis, B.A., Asst. Chemist

IVilliam T. Abel, B.A., Research Assistant

MELVIN A. ReBenstorf, B.S., Research Assistant

Jean Lois Rosselor, A.B., Research Assistant

\section{MINERAL ECONOMICS}

W. H. Voskuil, Ph.D., Mineral Economist

Douglas F. Stevens, M.E., Research Associate

Nina Hamrick, A.B., Research Assistant

Ethel M. King, Research Assistant

\section{PUBLICATIONS AND RECORDS}

George E. Ekblaw, Ph.D., Geologic Editor Chalmer L. Cooper, Pir.D., Geologic Editor Dorothy E. Rose, B.S., Technical Editor

Meredith M. Calkins, Geologic Draftsman

Beulah Featherstone, B.F.A., Asst. Geologic Draftsman

Willis L. Busch, Principal Technical Assistant

Portia Ally S Sith, Technical Files Clerk

Leslie D. Vaughan, Asst. Photographer

* Assistant Chief Chemist in interim of absence of Chief Chemist.

Consultants: Ceramics, Cullen W. Parmelee, M.S., D.Sc., and RalPh K. Hursh, B.S., University of Illinois Mechanical Engineering, SEICHI Konzo, M.S., University of Illinois

Topographic Mapping in Cooperation with the United States Geological Survey.

This report is a contribution of the Stratigraphy and Paleontology Division. 


\section{Digitized by the Internet Archive in 2012 with funding from \\ University of Illinois Urbana-Champaign}

http://archive.org/details/kinkaidcoralsfro113east 


\title{
KINKAID CORALS FROM ILLINOIS
}

\author{
WM. H. EASTON \\ Illinois State Geological Survey, Urbana
}

ABSTRACT-Three species of corals from southern Illinois are discussed. Two are good guide fossils and aid in correlating the Kinkaid limestone of Illinois and the Pitkin limestone of Arkansas. One new genus and one new species are described.

\section{INTRODUCTION}

$\mathrm{C}$ Corals are abundant locally in the Kinkaid limestone of southern Illinois but only one place is known where species other than the ever-present Triplophillites may be collected (Lamar, 1925, p. 80). A section measured there (a gully about 100 yards west of the road, 0.4 mile north of Cedar

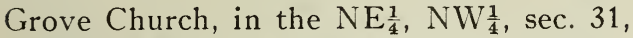
T. 11 S., R. 2 E., Johnson County, Illinois) is as follows:

Pennsylvanian

Caseyville group (Wayside formation)

17-19. Sandstone and platy shale

Mississippian or Pennsylvanian

14-16. Shale, gray, partly sandy or plastic, poorly exposed..............

Mississippian

Elvira group

Kinkaid limestone

13. Limestone and shale. Argillaceous, fossiliferous limestone which weathers brown, interbedded with gray and buff shale. Carries abundant Triplophyllites and Kinkaidia in the limestone.........................

12. Shale, dark gray, and blue-gray shale, probably with some thin limestone lenses. Partly covered................................

11. Limestone, gray, locally granular or nodular, in 9 - to 18 -inch beds. Highly fossiliferous; crinoid stems, large Archimedipora, and horned and colonial corals especially common. No brachiopods observed ............... Carries abundant Caninostrotion in lower part.

10. Shale, dark gray and blue-gray, plastic, with dark gray, granular limestone

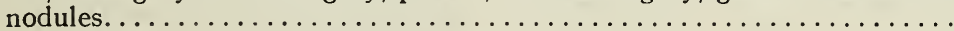

9. Limestone, gray, locally granular, fossiliferous $\ldots \ldots \ldots \ldots \ldots \ldots \ldots \ldots \ldots \ldots$

8. Shale, dark gray, partly concealed . . . . . . . . . . . . . . . . . . . .

7. Limestone, thin-bedded, slabby, gray. Prof usion of Myalina sp. Also numer-

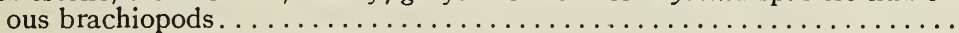

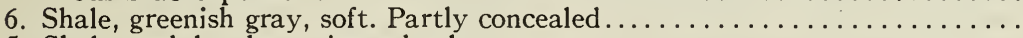

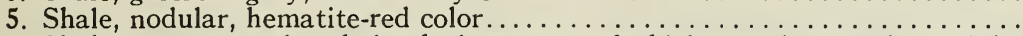

4. Shale, green-gray clay shale, the lower part of which contains angular nodules of dense, gray semilithographic limestone, and grades downward into the

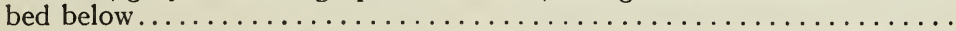

3. Limestone, nodular, dense, gray. Lower portion contains layers of shale and dark gray siliceous limestone . . . . . . . . . . . . . . . . .

2. Shale, with nodules of dense gray limestone. Partly concealed . . . . . . . . .

1. Limestone, siliceous, dark gray, with irregular cherty banding . . . . . . . . .
Thickness

Ft. in.

\section{6}

510

$16-$

$2 \quad 7$

184

110

17

$4 \quad 1$

43

$4 \quad$

$10-$

106 
are considered very sensitive to environmental changes, hence, it appears that migrational routes must have existed between the Kinkaid sea of Illinois and the Pitkin sea of Arkansas. Caninostrotion is abundant in the upper part of the Pitkin and common in only one observed bed of the Kinkaid, but on the other hand Kinkaidia is abundant in one bed near the top of the Kinkaid and has only been reported once from the (upper part of the) Pitkin. Considerably more work must be done on these faunas, especially on that of the Kinkaid, before definitive conclusions can be reached regarding connection of the seas. Even so, a partial emendation of the writer's previous views is in order.

The writer has stated (Easton, 1943, pp. 128-129) that "faunal migration from Europe or Asia apparently reached this ocean [lying south of North America] and certain corals of unique aspect migrated northward with the Pitkin sea but were unable to cross into the Illinois Basin," and that "there appears to be no evidence that the two basins were directly joined in Pitkin time." The extension of knowledge presented in this paper concerning the geographic distribution of the corals shows that the two basins probably were connected and that favorable ecologic conditions of unknown duration enabled faunal migration of some distinctive organisms. Not all of the Pitkin corals are yet known to have lived in the Illinois region during Kinkaid time and many other distinctive faunal elements either remain undiscovered in strata of the adjacent seas or actually did not cross a possible ecologic barrier between the seas.

\section{ACKNOWLEDGMENTS}

Collections were made with the assistance of Mr. C. L. Cooper and Mrs. Phoebe Beall Easton. Mr. G. A. Cooper lent Pitkin material for study and Mr. J. E. Lamar contributed information concerning his work at the Kinkaid locality.

\section{SYSTEMATIC DESCRIPTIONS}

The morphologic terminology used in this paper has been outlined previously by the writer (Easton, 1944).

\section{Phylum Coelenterata}

Class Anthozoa

Order Tetracoralla

Family Metriophyllidae

Genus Kinkaidia Easton, n. gen.

Diagnosis.-Simple, curved to cylindrical, rugose corals; counter septum long, may be rhopaloid; pair of counter-lateral septa bordering counter septum rather long, may be rhopaloid; cardinal septum short except in young stages; alar septa long, may touch counter septum even in mature stage; other major septa of equal strength, withdrawn from axis in mature stage, commonly rhopaloid; minor septa rudimentary; tabulae distally arched, both complete and incomplete types present; tabellae sparse, broadly arched; dissepiments absent.

Genotype.-Kinkaidia trigonalis, n. sp.

Remarks.-This genus differs from Claviphyllum Hudson, 1942, in having long alar septa in late stages, a relatively long counter-lateral septum on each side of the counter septum, and tent-like rather than globose tabellae. The two genera are very closely related, Kinkaidia being a potential ancestor of Claviphyllum; the former could give rise to the latter by reduction in length of the alar septa, by insertion of short septa between the counter septum and the counterlateral septa, and by increase in complexity of the tabellae.

Sochkineophyllum Grabau, 1928, is also related to Kinkaidia, differing from it in the absence of long alar septa and the long counter-lateral septum on either side of the counter septum, and in having several pairsof long rhopaloid (axially swollen) major septa.

Malonophyllum Okulitch and Albritton, 1935, though possessing the same general characters as the foregoing genera, lacks tabulae.

Lophophyllidium Grabau, 1928, may have been derived from Kinkaidia by reduction in length of the alar septa and by loss of the rhopaloid character of the major septa in late stages. The two genera resemble each other in the relative lengths of major septa (other than alars), in the nature of the tabulae, in the absence of dissepiments, and in the inconsistent development of minor septa. The stratigraphic occurrence of these 
two genera suggests that Kinkaidia might be the possible ancestor of Lophophyllidium. Claviphyllum, on the other hand, was contemporaneous with Kinkaidia.

\section{KINKAIDIA TRIGONALIS Easton, n. sp.} Figures 1-7

Externals.-Medium size, almost geniculate; calyx very deep; epitheca thick, bearing prominent interseptal ridges, septal grooves, encircling striae and rugae; cardinal fossula probably pronounced; alar pseudofossula indicated.

Transverse sections. - In early ephebic stage (diameters 4.1 by $6.0 \mathrm{~mm}$.) counter septum very long, almost in contact with relatively long cardinal septum; alar septa long but not reaching axis; counter-lateral septum on either side of counter septum slightly longer than other metasepta; four septa in each counter quadrant, three in each cardinal quadrant; septa noticeably swollen axially; tabular intersections sparse.

In middle ephebic stage (diameters 7.6 by $7.7 \mathrm{~mm}$.) counter septum and both alar septa about equal in length, meeting axially; cardinal septum very short, flanked on one side by three and on other by four metasepta which tend to lean toward cardinal septum; counter-lateral septum on either side of counter septum extend half of radius; counter quadrant contains five, the other, six septa; most septa axially swollen; tabular intersections common; minor septa suggested by only slight swellings of epitheca between majors.

At very slightly later stage another specimen has 25 major septa; counter septum long, much swollen axially; each neighboring counter-lateral septum long, one alar short; neither alar septa nor cardinal septum distinguishable; rudimentary minor septa present in most loculi.

In very late ephebic stage (diameters 10.7 by $10.7 \mathrm{~mm}$.), 24 major septa, alternating with equal number of short minor septa; counter septum very long; alar septa long, not quite reaching counter septum; counterlateral septum on either side of counter septum extends two-thirds of radius; cardinal septum short; four metasepta in one cardinal quadrant and three in other lean toward cardinal septum; counter quadrants contain six and seven septa; most majors rhopaloid.

Longitudinal section.-Tabulae both complete and incomplete, with rather sharply down-turned borders, slightly convex distally; tabellae broadly arched toward intersection of counter septum.

Remarks.-This species has been listed by the writer as "cup coral unidentified" (Easton, 1943, p. 130) from the Pitkin formation.

Ontogeny.-In earliest brophic stage (fig. 1a) only the epitheca is present, there being no septa or tabulae. The cardinal septum and the counter septum are inserted first to form an axial plate (fig. 1b). The right alar then appears (fig. 1c), followed by the left alar. At this stage, the top of the right alar has shifted somewhat axially (fig. 1d). Later the four primary septa become thickened, the alars move to positions nearly at right angles to the cardinal-counter plane and one alar septum is separated from axial contact with the other septa, the cardinal and counter septa separate slightly, and a tabula appears (fig. 1e). Metasepta, traceable as septal grooves on the epitheca, are inserted in the counter quadrants but are not always discernible in the thecarium (fig. 1f). By early neanic stage (fig. 1g) metasepta occur within the thecarium in thecardinal quadrants and tabulae are common; one counterlateral septum is noticeably longer than the neighboring septa and is axially swollen.

In early ephebic stage (fig. 4) there are 4 slightly rhopaloid septa in the counter quadrants and 3 in the cardinal quadrants; the counter septum is long and the cardinal septum is short; the counter-lateral septa are slightly longer than the neighboring septa. The typical features are observed in middle ephebic stage (fig. 6) where the counter septum and the alar septa meet axially, the cardinal septum is short, the counter-laterals are long; 5 or 6 septa occur in the counter quadrants and 3 or 4 are present in the cardinal quadrants, most of them being axially swollen; tabulae are common and may bear traces of septal extensions as spines. A section through a calyx at this stage gives indications of a pronounced cardinal fossula and observable alar pseudofossula (fig. 2a). In late ephebic stage (fig. 3) 


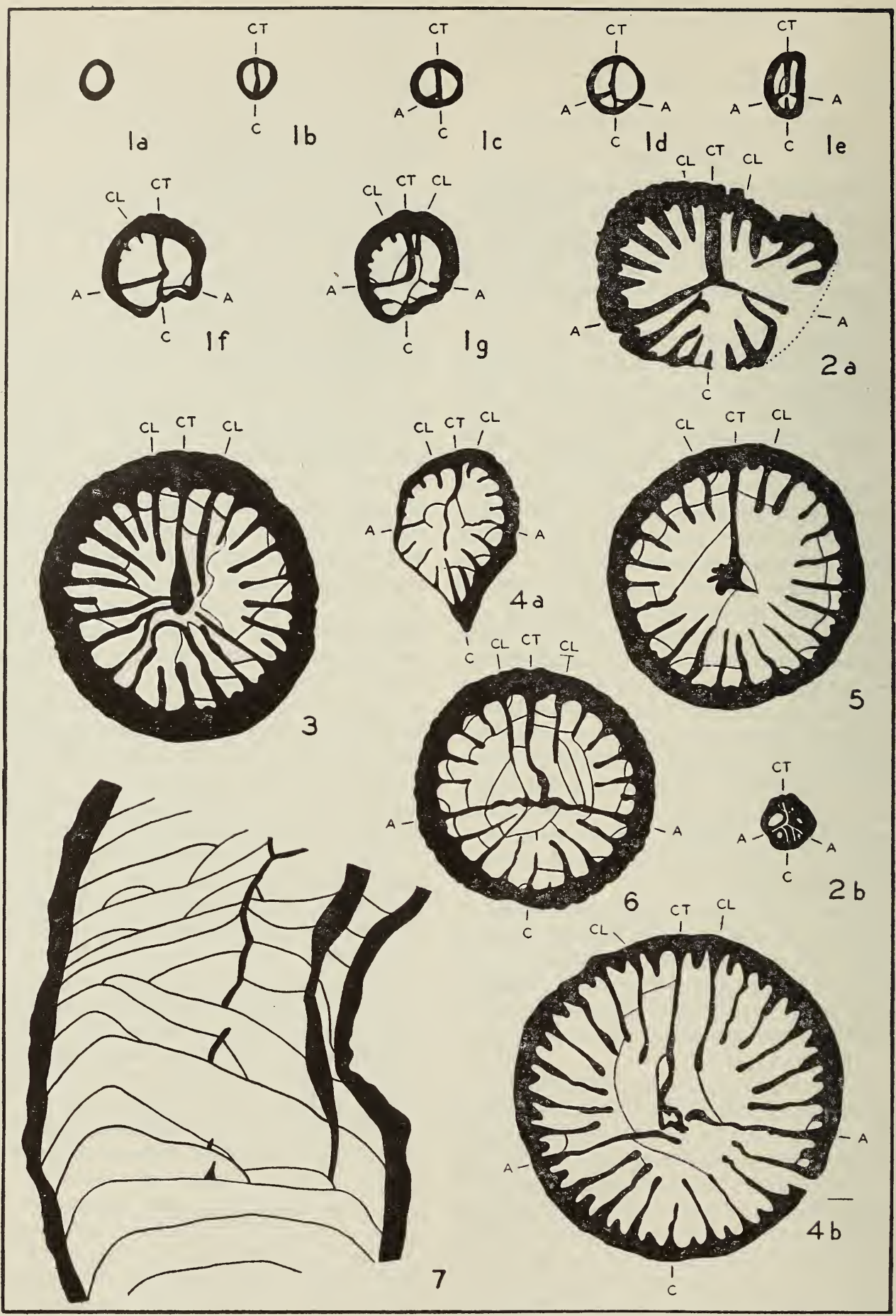

Figures $1-7$ 
the counter septum is markedly rhopaloid and rudimentary minor septa appear. Axial fusion tends to be dissipated in very late ephebic stage (fig. $4 \mathrm{~b}$ ), the majors are sinuous and axilly swollen, and minor septa are pronounced.

Occurrence.- Specimens were collected by the writer from bed 13 of the measured section at the Illinois locality. One specimen, collected by G. A. Cooper from the base of the (upper part of the) Pitkin formation, 3 miles east of Elkins, Arkansas, was lent for study.

Material.-The following specimens are in the collections of the Illinois State Geological Survey: holotype no. 3512; figured paratypes no. 3513; unfigured paratypes no. 3514. Figured plesiotype: U. S. National Museum.

Family HapsiphyLlidae Grabau emend. Easton, 1944

Genus Triplophyllites Easton, 1944

Remarks.-Triplophyllites was proposed for specimens generally identified as "Triplophyllum" in the United States. For a complete diagnosis of the genus and a discussion of its relationships, see Easton 1944, pp. $35-42$.

\section{Triplophyllites Palmatus Easton}

Triplophyllites palmatus Easton, 1944, Illinois Geol. Survey, Rept. Inv. 97, p. 35, pl. 8, figs. 1-6.

Remarks.-This species has been differentiated on the following characters (Easton, 1944 , p. 36).

"T. palmatus differs from $T$. spinulosusa (Grove) in having the cardinal septum short- ened by early ephebic stage; by its pronouncedly palmate grouping of septa in the counter quadrants, its very strong counter septum, and by the early reduction in the length of the cardinal septum. The generally trochoid shape, the very deep calyx, the strong interseptal ridges, and the sparse spines furnish external identifying characters."

This species has been figured recently in detail (Easton, 1944, pl. 8).

\section{Family Canininde}

Genus Caninostrotion Easton, 1943

Diagnosis.-(Easton, 1943, p. 134)

Compound rugose corals multiplying asexually chiefly by "peripheral increase" but possibly also by basal division. Cardinal fossula conspicuous in all but early stages, formed by down-bending of tabulae and shortening of cardinal septum. Dissepimentarium broad; dissepiments tend toward anguloconcentric pattern. Pseudocolumella intermittently developed, variable, formed by junction of axial ends of some major septa combined with distal arching of tabulae. Tabulae strong, irregularly arranged. Typically, septa are equally thickened in all quadrants.

\section{Caninostrotion variabilis Easton} Figures $8 \mathrm{a}, 8 \mathrm{~b}$

Caninostrotion variabilis Easton, 1943, Jour. Paleontology, vol. 17 , no. 2 , p. 134 , pl. 21 , figs. 14-16.

Externals.-Conical proximally, cylindrical distally; calyx deep, with septal traces on floor, steep-walled near floor, oblique near periphery; epitheca thin.

Transverse section.-In late ephebic stage (diameters 21 by $23 \mathrm{~mm}$.) dissepimentarium extends half of radius, consists of irregular anguloconcentric, concentric and herring

\section{Explanation OF Figures $1-7$}

Kinkaidia trigonolis, n. gen. and n. sp.; $\times 5$;

$1 a-1 g$-Successive, reversed, serial transverse sections from aseptate earliest brephic stage through early neanic stage.

$2 a$-Transverse section in open calyx; $2 b$, reversed transverse section near close of brephic stage.

3 -Reversed transverse section in late ephebic stage with rudimentary minor septa.

$4 a-$ Reversed transverse in early ephebic stage; $4 b$, transverse section in very late ephebic stage showing short secondaries and very long counter-laterals.

5-Transverse section in late ephebic stage; U.S. National Museum specimen from Pitkin formation.

6-Reversed transverse section in middle ephebic stage; holotype; Illinois Geological Survey No. 3512 .

7 -Longitudinal section.

All figures except 5 and 6 are of plesiotypes; Illinois Geological Survey No. 3513. 


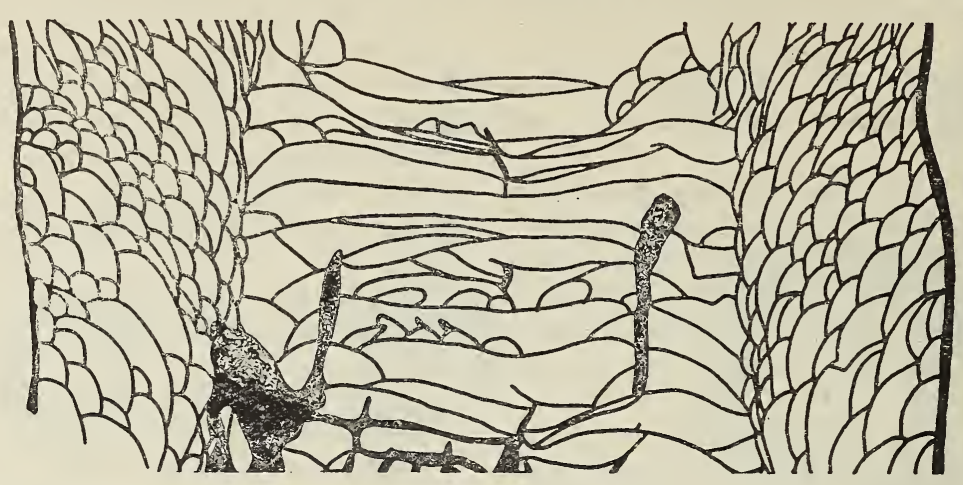

82

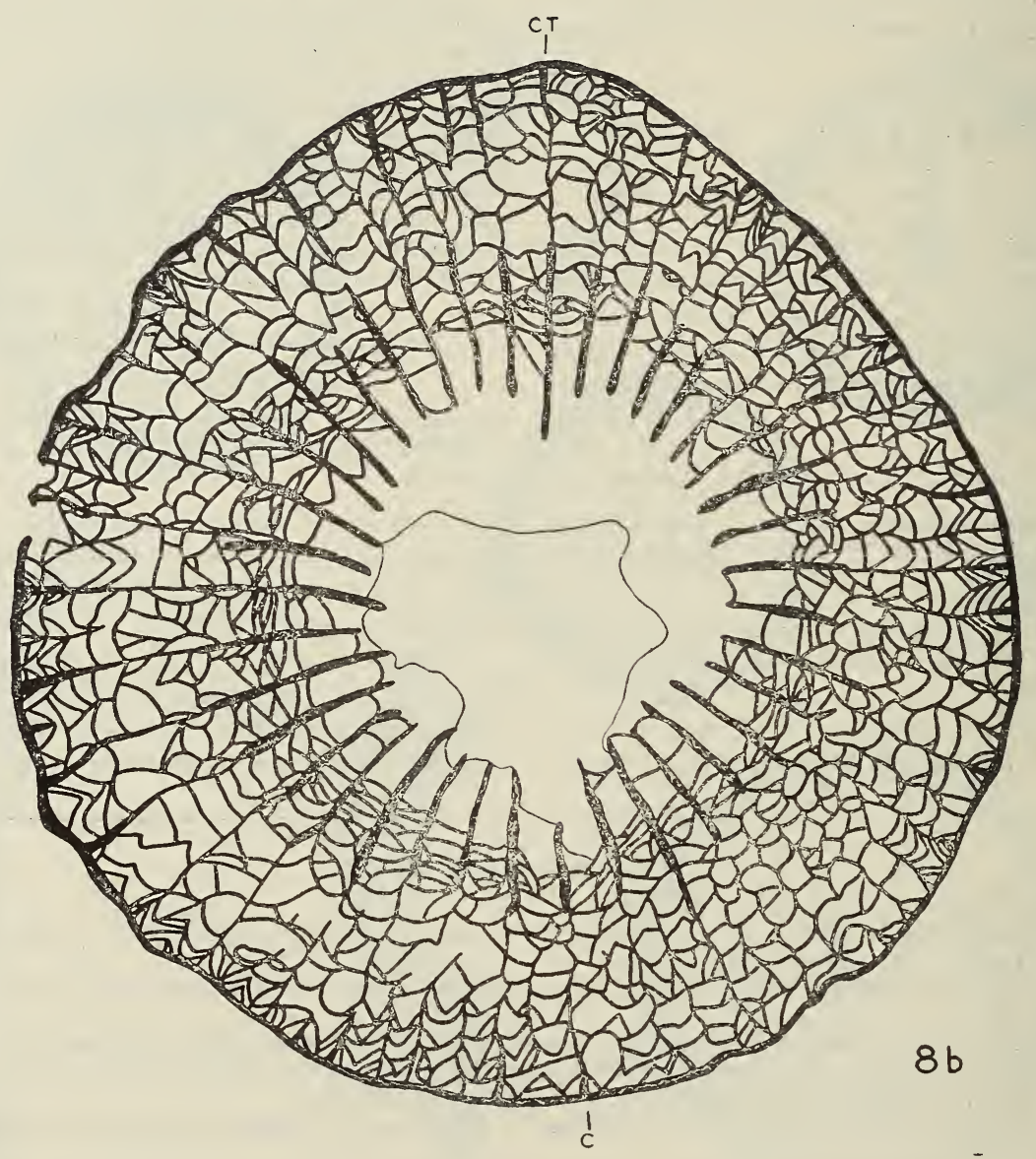

FIG. 8.-Caninostrotion variabilis Easton; plesiotypes; $\times 5$. $8 a$, Longitudinal section; $8 b$, transverse section; Illinois Geological Survey No. 3517 (p. 387). 
bone patterns with chevron-like dissepiments bordering major septa near epitheca; major septa extend three-fourths of radius, dilated within tabularium, weak to partially obsolete within dissepimentarium; cardinal septum short, flanked by somewhat pinnately arranged major septa; counter septum long; minor septa obscure to obsolete.

Longitudinal section.-Dissepiments of unequal size, slightly elongate; tabulae complete and incomplete, with moderately down-turned peripheries and axial portions slightly arched distally; tabular density about 22 per $\mathrm{cm}$.; pseudocolumella intermittently present.

Remarks.-Although smaller than the original specimens from the Pitkin formation, these Illinois corals have no other differentiating characteristics and are therefore considered conspecific with $C$. variabilis.

ManusCript ReCeived April 6, 1944.
The species has been previously listed as "Cup coral n. gen. et. n. sp." (Easton, 1942, p. 84) from the Pitkin formation.

Occurrence.-Common near base of bed 11 of the measured section at the Illinois locality.

Material.-Figured plesiotypes: Illinois State Geological Survey No. 3517; unfigured plesiotypes: No. 3518.

\section{BIBLIOGR A PHY}

Easton, W. H., 1942, Pitkin limestone of northern Arkansas: Arkansas Geol. Survey Bul. 8. 1943, The fauna of the Pitkin formation of Arkansas: Jour. Paleontology, vol. 17, no. 2, pp. 125-154.

p. 1944, Corals from the Chouteau and related formations of the Mississippi valley region: Illinois Geol. Survey Rept. Inv. 97.

LAMAR, J. E., 1925, Geology and mineral resources of the Carbondale quadrangle: Illinois Geol. Survey Bull. 48. 


\title{
AMPLEXOID CORALS FROM THE CHESTER OF ILLINOIS AND ARKANSAS
}

\author{
WM. H. EASTON
}

\begin{abstract}
Three new corals are described from the Paint Creek, Golconda, and Fayetteville formations, and one from the Renault is redescribed. The ontogenies of three species are discussed and figured in detail. Possible phylogenetic relationships are considered. Protosepta are inserted in this order: axial septum, left alar septum, right alar septum, left counter-lateral septum, and right counter-lateral septum.
\end{abstract}

\section{INTRODUCTION}

$\mathrm{T}$ HIS study is offered to bring to light three new species of Chester corals which can be used in correlation and to present detailed discussions of the ontogenetic development of Chester species generally referred to Amplexus. A large number of specimens was studied, many of which possessed complete apical portions.

\section{SEPTAL INSERTION AND PHYLOGENY}

Two recent papers contain excellent bibliographies of ontogenetic studies of rugose corals. Grove (1934) has presented a detailed objective review of the principal studies of fossil corals and Hill $(1935$, pp. 505, 506) has published a very concise statement of the septal arrangement among the rugose corals, which is quoted below.

Insertion of meta-septa takes place at four points, ${ }^{1}$ immediaately on each side of the cardinal septum, and on the counter side of each alar septum.

Referring, first to the cyathaxonid type, insertion of meta-septa is always accompanied by insertion of minor septa as follows [fig. 1b]:- -2 On each side of the cardinal [C] and both counter-lateral $[C L]$ septa a new short septum arises. Those [1X] on the counter side of the counter-lateral septa remain short and are minor septa; the others [1] lengthen, and immediately on each side of them a new short septum arises. That on the counter side [2X] remains short and is a minor septum; that on the cardinal side [2] lengthens to become a major septum, and two new short septa are inserted one on each side of this new major septum, the one on the counter side [3X] being a minor septum, and the other [3] growing to become a major septum, and so on.

1 Exceptions are known. er's.

${ }_{2}$ This and subsequent brackets are the writ-
In a second group [fig. 1a, the zaphrentid type], by far the largest, at first af ter the insertion of the six proto-septa, only meta-septa arise at the four points of insertion, and minor septa (which in this group are obviously delayed) later appear in rapid succession in all the loculi, after which major and minor septa arise at each point of insertion as in the first group.

It is not yet fully agreed as to whether the rugose corals have four or six primary septa, the counter-lateral septa being called metasepta by some students. Disregarding the philosophical implications, however, it has been demonstrated that the order of insertion of the first six septa is as reviewed by Grove $(1934$, pp. 119,120$)$ :

I. A single septum stretches entirely across the calicle, from wall to wall. At a considerably later stage this breaks near the center, the two halves forming the cardinal and counter septa. This first formed septum Carruthers designated as the "axial septum."

II. Two new septa arise, one on either side of the axial septum, at its cardinal end. These remain attached to the wall of the corallum and to the axial septum, but gradually spread outwards, and eventually become the alar septa.

III. A second pair of septa appear at the counter end of the axial septum, and similarly spread outward, but to a much more limited extent than the first pair.

Grove goes on to say that the "disruption of the axial septum completes the formation of six primary septa," but this does not always happen at this stage; indeed, it may not happen until a much later stage, if at all.

All four of the amplexoid corals considered here have the zaphrentid type of septal insertion. The species restricted to the Paint Creek formation differs from the others in having an early mature stage in which the septa of the counter quadrants are dilated and in having short or rudimentary minor 
septa in very late mature stages. This species appears to be related to $A$ mplexus rockfordensis Miller and Gurley. The other three species are apparently closely related members of the Hapsiphyllidae. The nature of septal insertion and the presence of cardinal
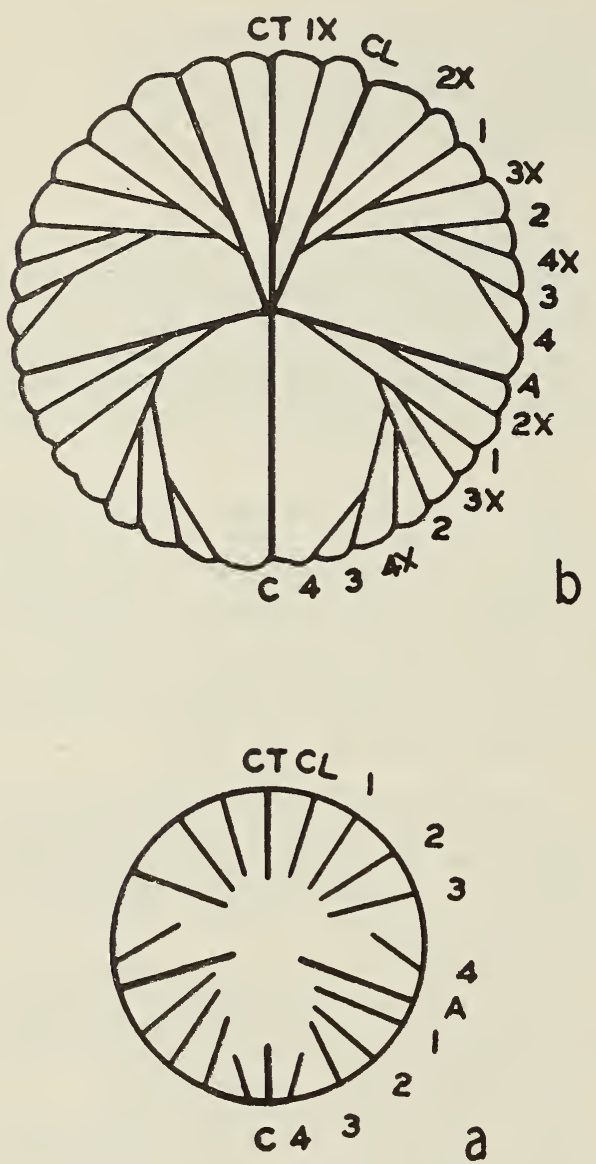

FIG. 1 $a, b$--Principal systems of insertion of septa in the rugose corals. 1a, "zaphrentid" type; $1 b$, "cyathaxonid" type; A, alar septum; C, cardinal septem; CL, counter-lateral septum; CT, counter septum; 1-4, major metasepta; $1 \mathrm{X}-4 \mathrm{X}$, minor metasepta. (Modified from Hill, 1935.)

fossulae and of alar pseudofossulae at some stage in each of these species are strong arguments for assigning such a relationship.

Early septal insertion in these amplexoid corals as found by the writer starts with an aseptate condition, after which the axial septum appears. The left alar is next in- serted, followed by the right alar, the left counter-lateral, and the right counterlateral septa in that order. The first metaseptum is inserted in the left counter quadrant and the second metaseptum is inserted in the right counter quadrant. Axial fusion of the primary septa tends to persist into mature stages. This order of insertion is somewhat at variance with that commonly understood to obtain in that most writers have found the alar septa to be inserted simultaneously as a pair, followed by the counter-lateral septa also as a pair. The writer (Easton 1945, p. 385) found that the right alar system was the first to be inserted after the axial septum in Kinkaidia trigonalis.

Contratingent minor septa, which lean toward the counter quadrants and are joined to the next adjacent major septa are well known and aid in rapid orientation of sections, but the writer is not aware that anyone has pointed out the apparent contratingent nature of tabular intersections near the epitheca in those corals in which the peripheral edge of a tabula slopes from the counter position proximally toward the cardinal position. This feature can be used to orientate sections (pl. 87 , figs. 12, 13) in which the septa are not capable of differentiation on other grounds.

The writer noticed several abnormalities of septal relationships during this work. The amplexoid trend is apparently increasingly strong as maturity progresses, but some septa in early stages may be withdrawn after insertion. The position of a septum may be clearly established from study of septal grooves, but the actual insertion of the septum may be retarded. Occasionally, one will find in the counter quadrants a metaseptum attached to the alar septum for a time, rather than to the next preceding metaseptum. The rate of septal insertion is subject to wide extremes of variation in a single species, as exemplified by very rapid insertion of septa, followed by very slow insertion. Examples in which one of a pair of quadrants contains more metasepta than the other are common and are usually indicative of contortion or geniculation of the corallite. In the attached apical portion of one species, the alar septa, though presumably tending to be inserted 
in normal sequence, are not observable until after a counter-lateral septum appears, their actual presence apparently being indicated, however, by slight internal swelling of the epitheca (pl. 86, fig. 2a). Further study of sections in the same sequence bears out the observation that the arrangement of septa is independent of the effects of attachment, for the plane of attachment cuts across the plan of septal arrangement without their being any adjustment of the center of symmetry.

\section{ACKNOWLEDGMENTS}

The writer is indebted to Carey Croneis of Walker Museum, University of Chicago, and R. C. Moore of the University of Kansas, for lending specimens used in this study. Some locality data were furnished by J. Marvin Weller.

\section{SYSTEMATIC DESCRIPTIONS \\ Phylum Coelenterata Class Anthozoa \\ Order TETRACORALla \\ Family HAPSIPHYLLIDAE \\ Genus Amplexus of authors}

Diagnosis.-Simple, conico-cylindrical, rugose corals with broad generally complete tabulae; septa more or less radial in arrangement, extending to the axis over the upper surfaces of most tabulae, but extending distally from each tabula a progressively shorter distance as the axis is approached; dissepiments and columellar structure absent.

Occurrence.-Silurian to Permian of many parts of the world.

Remarks.-Amplexus (sensu stricto) was founded upon $A$. coralloides by Sowerby in 1814 , but since that time a wide variety of species has been referred to this genus on the basis of their simple structure. Type material of $A$. coralloides has never been sectioned in early stages, hence, the morphology of the genotype is inadequately known. Paleontologists now seem to be generally agreed that corals of simple structure similar to $A$. coralloides may very well belong to some genus other than $A$ mplexus, but ontogentic studies still largely remain to be done before polyphyletic relationships of " $\mathrm{Am}$ plexus" can be demonstrated satisfactorily.
- Amplexus adnatus Easton, n. sp.

Plate 85, figure 9; plate 87, figures 1-7

Externals.-Ceratoid to trochoid geniculate corals with apical angle usually about $20^{\circ}$; epitheca with numerous rather fine encircling wrinkles, prominent septal grooves and interseptal ridges which always originate in connection with a pair of adjacent septa; spines commonly extending from one side, especially near apical end, parracidal increase common, with new calyx starting from some eccentric position and with epitheca commonly grown over old calyx. Average length about $20 \mathrm{~mm}$. with range from about 10 to $30 \mathrm{~mm}$.; average diameter about $6 \mathrm{~mm}$., but flared specimens may be $11 \mathrm{~mm}$. in diameter at calyces.

Transverse sections.- Septa not numerous, mostly reaching center, even in late stages. (See "ontogeny" for details.)

Longitudinal section.-Tabulae nearly all complete, with little or no axial sag, relatively abruptly recurved proximally near peripheries.

Occurrence.-Abundant in the Golconda formation in the Vienna quadrangle. Collected by Stuart Weller from his locality W312 , which may be the $\mathrm{E}_{\frac{1}{2}}, \mathrm{NW}_{\frac{1}{4}}$, sec. 28, T. 13 S., R. 3 E., near top of the bluff on the high point of land between two creeks $4 \frac{1}{2}$ miles south-southeast of Vienna, Illinois; also occurring in the Paint Creek formation.

Material.-Holotype, No. 47248; paratypes and topotypes, not numbered; all in Walker Museum, University of Chicago. Ideotypes, Walker Museum No. 47249, Illinois State Geological Survey No. 3537.

Ontogeny. - The earliest stage observed (pl. 87, fig. 1a) has an axial septum which consists of the fused cardinal septum and counter septum. In the next observed stage (fig. 1b) both alar septa are present, of which the left is the thicker and has migrated farther from the cardinal septum, therefore, it probably was inserted before the right alar. Other stages were not observed before that in which the left cardinal quadrant contains one metaseptum, the right cardinal quadrant none, the left counter quadrant the probable counter-lateral septum, and the right counter quadrant one metaseptum and the counter-lateral septum (fig. 1c). This asymmetrical arrangement presumably is a manifestation of geniculation of the corallite. 
Next (fig. 1d) each cardinal quadrant contains one metaseptum and each counter quadrant contains two metasepta. It will be noticed that the metasepta of the left counter quadrant are aberrant in that they lean toward the alar septum and that some of them may not reach the axis (figs. 1c-1f). Traces of tabulae can be observed in the last mentioned stage (fig. 1f), and the alar pseudofossula is developed only on the right side of the coral. The right alar pseudofossula still persists when 14 major septa are present (fig. 2), and each cardinal quadrant has one well developed metaseptum attached to the cardinal septum. The cardinal fossula soon becomes apparent but the alar pseudofossulae are represented only by slightly wider loculi than occur elsewhere; the cardinal quadrants each contain two metasepta and the counter quadrants three or four (fig. 3). When 16 major septa have been inserted (fig. 4), there are three metasepta in each cardinal quadrant and three or four septa in each counter quadrant, but several septa have retreated a short distance from the axis. At full maturity (fig. 5) there are 22 major septa, of which three are in each cardinal quadrant and six in each counter quadrant, thus, the counter quadrants are accelerated by the time maturity is reached. Amplexoid retreat is very poorly shown, inasmuch as those septa which do not reach the axis are either fused near their axial edges, or else lean against a neighboring metaseptum. The amplexoid condition is developed by middle maturity, nevertheless, as shown by a section just below a tabula (fig. 7).

Comparison.-This species can be distinguished externally from the other species of Amplexus by the small size of the corallites, their contorted shape, nearly cylindrical mature portions, calical method of increase, occasional development of spines on one side, about twice as many septal grooves as septa, and by the insertion of two adjacent septa as a pair.

Remarks.-Septal notation was verified through study of the septal grooves wherever possible. In this regard, it was observed that although minor septa are nowhere developed, a septal groove usually occurs between major septa, hence there are usually about twice as many septal grooves as septa.
Ontogenetically, this species is characterized by the slow rate of insertion of major septa, by marked acceleration of the counter quadrants in mature stages, and by very poorly developed amplexoid retreat.

Phylogenetic relationships are with the so-called "zaphrentid" types, except that the fossulae are poorly developed and primary septa tend to remain fused axially. $A$. adnatus appears to be closely related to A. geniculatus.

Apical portions of most corallites are so contorted and spinose that study of epithecal ornament is unsatisfactory, however, it was noted in some specimens that the cardinal position is on the convex side of the corallite. It is not known how general this may be, for the cardinal position was also observed to be on some other side in a few specimens.

Wherever observed, the corals were attached by spines to a fragment of a fenestellid bryozoan. One coral has two distinct and separate patches of spines and is geniculate in such a manner as to suggested that the animal originally was recumbent along a bryozoan frond and then altered its direction of growth in order to make the corallite vertical, but the bryozoan frond either broke or its position was changed so that the coral was again recumbent and sent out spines.

Amplexus dilatatus Easton, n. sp. Plate 85 , figure 10 ; plate 86 , figures 4,5 Caninia n. sp. Weller, 1920, Illinois Geol. Survey, Bull. 41, pp. 170, 173.

Externals.-Curved ceratoid corals; epitheca nearly smooth with encircling wrinkles, relatively faint septal grooves and interseptal ridges, occasionally with sparse spines; calyx rather deep, vertically walled; calical increase observed, with epitheca grown over old calyx. Mature specimens about $3 \mathrm{~cm}$. long; diameter of calyx about $10 \mathrm{~mm}$.

Transverse sections.-Mature section of holotype (pl. 86, fig. 4b) has 27 major septa extending about half the radius, of about equal strength but cardinal and counter septa are slightly longer than other major septa; minor septa short or rudimentary.

In early maturity (fig. 4a) holotype has 19 major septa; cardinal septum short; metasepta of cardinal quadrants pinnately arranged: alar septa al most reach axis; septa 
of counter quadrants somewhat dilated, three grouped in palmate bunches on either side of long counter septum; minor septa rudimentary.

At slightly earlier stage (fig. 5) in a paratype, septa of counter quadrants much dilated; septa of cardinal quadrants thin, sinuous.

Longitudinal section.-Not prepared.

Occurrence.-All specimens are from thin limestone lenses in Paint Creek shale about 10 to 15 feet below the Cypress sandstone, on the south bluffs at Indian Point overlooking the valley of Cache River, in sec. 32, T. 13 S., R. 3 E., Johnson County, Illinois.

Material.-Specimens studied, 3; holotype, no. 47247; figured paratypes, not numbered; all in Walker Museum, University of Chicago, collected by Stuart Weller.

Ontogeny.-Early stages not preserved.

Comparison.-This species differs from the other Chester amplexoid corals in having the septa of the counter quadrants dilated in early maturity, and in having relatively strong development of minor septa.

The species can be identified externally by its curved conical shape, sparse spines, and common occurrence of the cardinal position on the convex side of the corallite.

Remarks.-A. dilatatus has typical socalled "zaphrentid" type of septal pattern. It appears to be related to $A$. rockfordensis from the Rockford beds (Kinderhook) of Indiana.
Amplexus expansus Easton, n. $\mathrm{sp}$.

Plate 85 , figure 8 ; plate 86 , figures $1-3$

Externals.-Ceratoid, slightly curved with apical angle about $30^{\circ}$; epitheca generally with fine encircling striae distally but with septal grooves and interseptal ridges proximally, wrinkled throughout; apical end recurved, commonly much less flared than rest of coral, with very fine encircling striae, flattened on one side (cardinal side wherever observed) where apparently attached to foreign body; sections reveal rather deep calyx (about $\frac{2}{5}$ length of corallite) vertically walled and lined with septa. Specimens range in length from about $1.5 \mathrm{~cm}$. to 3.5 $\mathrm{cm}$.; diameter of calyx about $12 \mathrm{~mm}$.; early attached portion from 2 to $4 \mathrm{~mm}$. long.

Transverse sections. - Septa become amplexoid rapidly, beginning their retreat at stage of about 17 septa. (See "ontogeny" for details.)

Longitudinal section.-Tubulae nearly all complete, about 8 in $1 \mathrm{~cm}$., recurved proximally near peripheries and with proximal sag in axial region.

Occurrence.-Fayetteville shale, 6 miles east and 1.5 miles north of Vinita, Oklahoma. Collected by Maurice Wallace and Arthur Bowsher.

Material.-Specimens studied, 37; holotype, figured paratypes, unfigured paratypes, and topotypes, not numbered; all in the collections of the University of Kansas.

Ontogeny.-Most of the septa are inserted
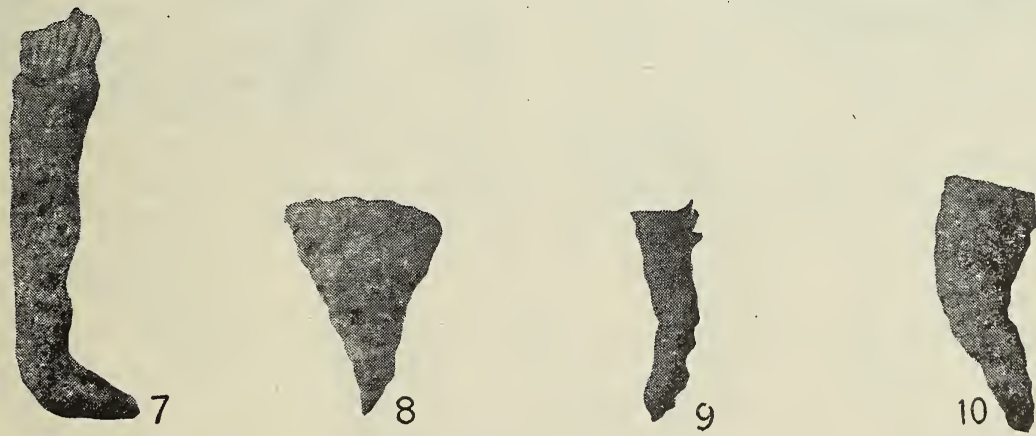

\section{Explanation of Plate 85}

FIGs. 7-Amplexus geniculatus Worthen. Side view; holotype; XI; Illinois State Geological Survey (Worthen collection) No. 2566a.

(p. 630)

8-Amplexus expansus Easton, n. sp. Side view; paratype; XI; University of Kansas. (p. 629)

9-Amplexus adnatus Easton, n. sp. Side view; holotype; XI; Walker Museum No. 47248.

10-Amplexus dilatatus Easton, n. sp. Side view; holotype; XI; Walker Museum No. 47247. 
in the very early unflared portion of the corallites (pl. 86, figs. 1a-1h, 2a-2h). Although not actually observed, the earliest stage presumably is aseptate. The earliest observed stage (fig. 1a) has an axial septum extending across the center of the thecarium consisting of the fused cardinal septum and counter septum. In every observed instance, the cardinal septum is more or less normal to the plane of attachment of the corallite. At the next stage (fig. 2a) the left counterlateral septum is inserted but this apparently unorthodox sequence is caused by the alar septa being crowded against the epitheca parallel with the plane of attachment and only faintly observable in sections; they are first clearly seen at the next stage (fig. 2b) which has an axial septum, counter-lateral septa, and the fully developed alar septa starting to become separate from the epitheca. The coral grows larger (fig. 2c) and eventually adds a metaseptum in the left counter quadrant (fig. 2d) and then another in the right counter quadrant (fig. 2e). This corresponds to about the same stage shown in figure $1 \mathrm{~b}$, but the latter specimen is aberrant in having the center of symmetry offset toward the counter position. There may be a tendency after this stage for the septa to retreat from the axis (figs. $1 \mathrm{c}-1 \mathrm{f}$ ), but even though this occurs, the septa may reverse the trend (figs. $1 \mathrm{~g}-1 \mathrm{i}$ ) before beginning their final retreat (fig. $1 \mathrm{j}$ ) and attaining maturity (fig. 2i). After two metasepta have been inserted along with the alar septa, a metaseptum appears in the left cardinal quadrant (fig. 1c) and then another in the right cardinal quadrant (fig. 2f). When each counter quadrant has four septa, and the cardinal quadrants each have two metasepta, the final septal retreat (fig. 1i) starts by axial thinning of septa. Alar septa and the counter septum are longer than other major septa and the cardinal septum soon becomes quite short (fig. 1j), but in maturity (fig. 2i) the alar septa and the cardinal septum are shorter than the others and the counter septum is the same length as the neighboring metasepta.

Comparison.-This species is readily identified externally by the flaring corallites and by the brephic stage in which the epitheca is equipped with very fine encircling striae and bears the flattened area where it was attached to some foreign object (patterns of costate brachiopod shells were commonly observed). These features serve to distinguish $A$. expansus from other Chester amplexoid corals.

Remarks.-Ontogenetically, this species is characterized by early and rapid retreat of the major septa, by insertion of about half the total number of major septa before notable flaring of the calyx begins, by nearly radial arrangement of septa in late stages, and by nearly uniform thickness of major septa in late stages.

Phylogenetic relationship is with the socalled "zaphrentid" types but the species is clearly of different ancestry than the other Chester "Amplexus."

Amplexus geniculatus Worthen

Plate 85 , figure 7 ; plate 87 , figures 8-14 Amplexus geniculatus Worthen, 1890, Illinois Geol. Survey, vol. 8, p. 82, pl. 10, figs. 7, 7a.

Externals.-Large simple corals, commonly geniculate near apical end and occasionally contorted in cylindrical portion; calyx rather deep, nearly vertically walled; epitheca occasionally spinose but always with very prominent septal grooves and interseptal ridges; corallites commonly ceratoid to trochoid near a pical end, with abrupt change to nearly cylindrical shape, or gradually expanding. Average length about

\section{Explanation of Plate 86}

FIgs. 1-3-Amplexus expansus Easton, n. sp.; paratypes; University of Kansas collections; $\times 5$. $1 a-j$-Transverse serial sections; reversed; 1 specimen. $2 a-i-$ Transverse serial sections; reversed; 1 specimen. 3-Longitudinal section.

4-5-Amplexus dilatatus Easton, n. sp.; Walker Museum collections; $\times 5$. 4a- $b-$ Transverse sections; holotype; No. 47247.5-Transverse section; reversed; paratype.

(p. 628) 


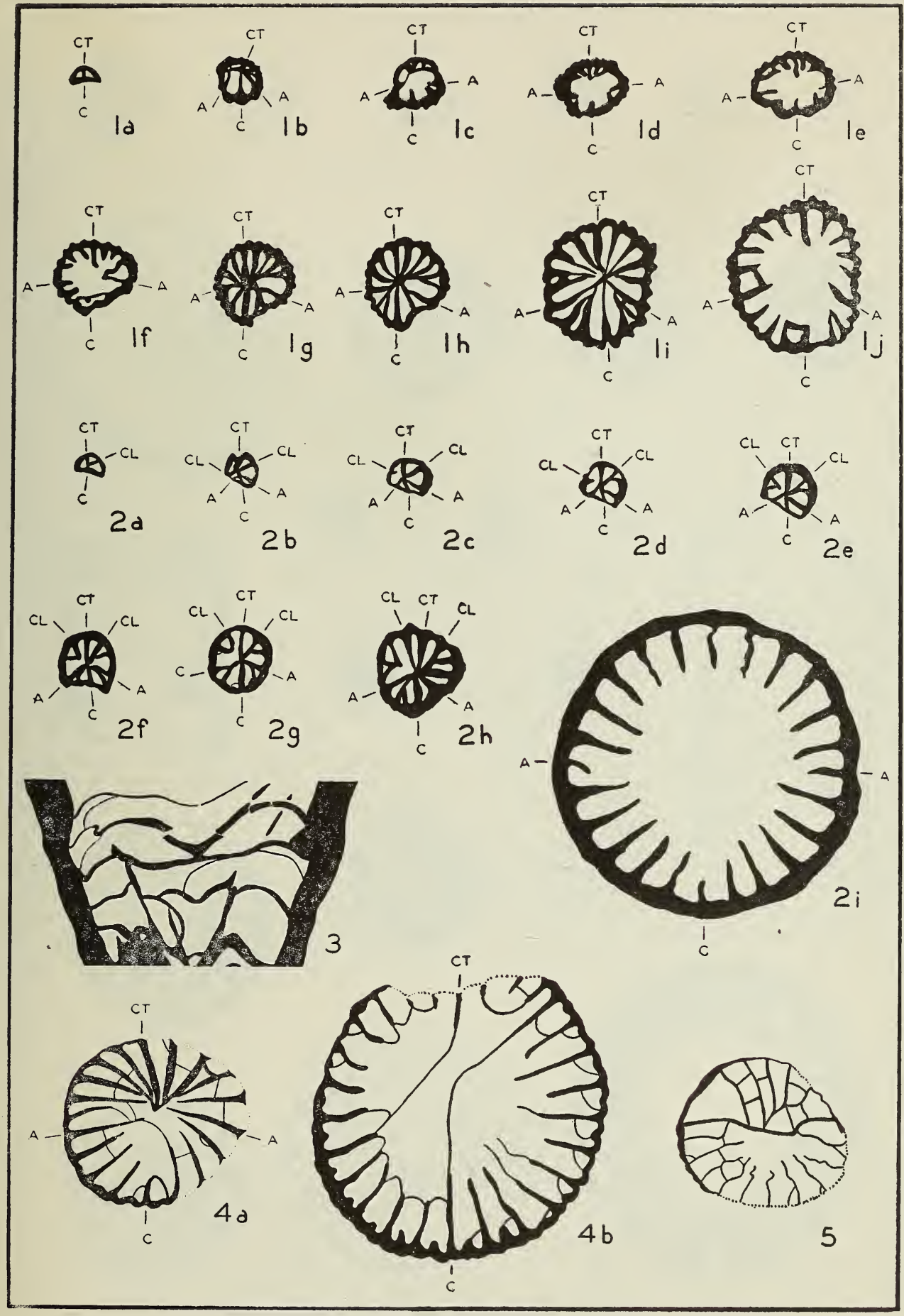

Easton-Chester Corals 
Journal of Paleontology, Vol. 19

Plate 87

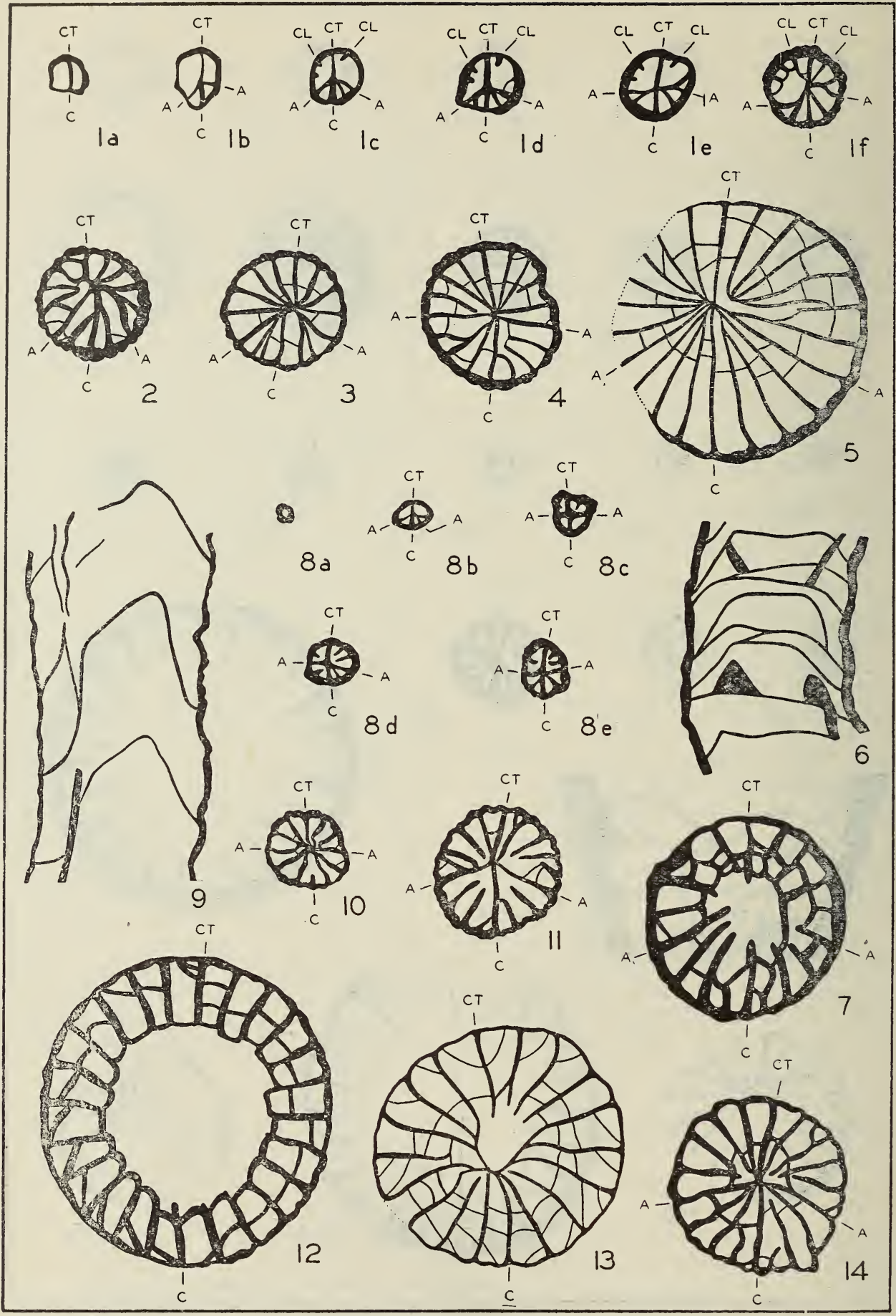

Easton-Chester Corals 
$4.5 \mathrm{~cm}$.; average diameter at calyx about $9 \mathrm{~mm}$.

Transverse sections. - Septa thin, relatively iew in number, generally meet at axis; tabular intersections common, straight. (See "Ontogeny" for details.)

Longitudinal section.-Tabulae about 4 $\mathrm{mm}$. apart, highly arched distally, the peripheral edges sloping proximally from counter to cardinal position.

Occurrence.-The type locality was originally given as "Chester limestone, Pope County, Illinois," but subsequent studies have shown the species to be restricted to the Shetlerville member of the Renault limestone of Lower Chester age.

Material.-Specimens studied, 62; holotype, Illinois State Geological Survey (Worthen collection) No. 2566a; paratype, same collection, No. 2566b; figured plesiotypes, Illinois State Geological Survey No. 3526-3531, 3536, and University of Illinois No. X-1479; unfigured plesiotypes, Illinois State Geological Survey Nos. 3532-3535. The writer has studied Illinois specimens from the grey-green shale cropping out on the east bank of the ravine above the old Bean and McMaster's quarry near Shetlerville; from $\frac{3}{4}$ mile south of Eichorn; from Melcher Hill in Hardin County; and from the ravine east of Shetlerville.

Ontogeny.-Before any septa are inserted (pl. 87, fig. 8a) there is simply a ring of epitheca. Presumably septa are inserted in an orderly manner as in the other species studied, in which case the axial septum extended across the thecarium, then the left alar, right alar and left counter-lateral septa were inserted (fig. $8 \mathrm{~b}$ ) but these stages have not been observed. The alar septa migrate toward the counter septum until they stand at right angles with the axial septum, by which time the right counter-lateral septum has appeared (fig. 8c). The next observed stage (fig. 8d) shows one metaseptum in each cardinal quadrant and one metaseptum and the counter-lateral septum in the left counter quadrant and the counter-lateral in the right counter quadrant. These relationships persist a short time (through fig. 8e). but in the next section (fig. 10) each quadrant has one metaseptum in addition to a counter-lateral septum, and tabulae occur. Subsequently, acceleration of the counter quadrants occurs and they contain four or five septa while the cardinal quadrants contain two or three metasepta (fig. 11). By this stage most of the metasepta are withdrawn from the axis, although they have shown an impersistent tendency to retreat since an early stage (fig. 8c). Moreover, the epitheca is lined with septal grooves between major septa, but this suggestion of minor septa is probably misleading because the grooves seem to correspond with longitudinal wrinkles inside the thecarium, rather than to actual rudimentary minor septa. Later, rudimentary minor septa are definitely present. At full maturity, the septa are usually about 20 to 24 in number and occur in many different patterns, varying between a radial arrangement in which most septa nearly or quite reach the axis (fig. 14) and the typical amplexoid pattern (fig. 12) in which the septa are withdrawn toward the periphery and do not extend vertically throughout their length between adjacent tabulae. An intermediate pattern (fig. 13) is obtained if the plane of a section passes just below a tabula.

\section{Explanation of Plate 87}

Figs. 1, 6, 13-Amplexus adnatus Easton, n. sp.; paratypes; Walker Museum collections; $\times 5$. 1a-f7, Transverse serial sections; reversed; 1 specimen. 2-4-Transverse sections; reversed; 3 specimens. 5-13-Transverse sections; 2 specimens. 6-Longitudinal section. 7-Transverse section just below a tabula.

(p. 627)

8-12, 14 -Amplexus geniculatus Worthen; plesiotypes; Illinois State Geological Survey collection, except fig. $13 ; \times 5.8 a-e-$ Transverse serial sections; reversed; 1 individual; No. 3526. 9-Longitudinal section in cardinal-counter plane; No. 3527. 10-12-Transverse section; reversed; 3 specimens; Nos. 3528, 3529, 3530. 13-Transverse section; No. 3526. 14-Transverse section, reversed; University of Illinois No. X-1479.

(p. 630) 
Remarks.-Ontogenetically, this species is characterized by the marked acceleration of the counter quadrants and by the slow insertion of metasepta after very early maturity.

Phylogenetic relationships are clearly with the so-called "zaphrentid" types, and $A$. geniculatus appears to be closely related to A. adnatus.

This species is readily identified externally by the large, long, slender corallites which may be geniculate and sparsely spinose and almost always show interseptal ridges and septal grooves.

\section{REFERENCES}

EAston, W. H., 1945, Kinkaid corals from Illinois: Jour. Paleontology, vol. 19, no. 4, pp. 383-389.

Grove, B. H., 1934, Studies in Paleozoic corals: Am. Midland Naturalist, vol. 15, no. 2, pp. 97137.

HILL, D., 1935, British terminology for rugose corals: Geol. Mag., vol. 72, no. 11, pp. 481-519.

MANUSCRIPT RECEIVEd JUNe 9, 1944. 